\title{
Growth or Development? A Sustainable Approach
}

\section{Teresa Dieguez}

Polytechnic Institute of Cávado and Ave (IPCA), Portugal \& Polytechnic Institute of Porto (IPP), Portugal teresadieguez@gmail.ipca

\begin{abstract}
Economic growth and development are concerns of humankind. Resources are limited but people seems don't care about it as they take unreasonable measures with irreversible effects. Sustainable Development is a necessity to meet the needs of future generations and not only a practice of corporate social responsibility to gain a competitive edge. Challenges are huge, requiring the commitment of all citizens. People should be more informed and aware of the imbalance caused by the yearning for power and economic growth, forgetting the balance of social and environmental dimensions. Big changes are needed from all and it is clear a need of paradigm shifting. Collective shared visions must build new strategies to shape a better world. Concerns related with sustainability began 200 years ago, but what have humankind really done about it? This study looks at this theme from the eighteenth century until today.
\end{abstract}

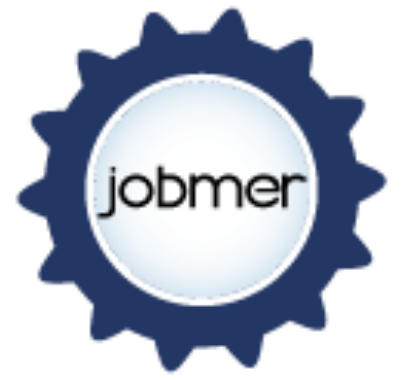

Journal of Business Management and Economic Research Vol.2, Issue.8, 2018 pp.38-46

Doi: 10.29226/TR1001.2018.56

Key-words: Education for Sustainable Development; Beginning; Retire; Endless loop; Sustainable Development; Standoff

\section{Introduction}

The world is changing, facing catastrophes, wars, imbalances, epidemics and injustices. Complex times without record in history, involving a problem that connects locally and globally environmental, economic, social and technological issues (Harris, 2007).

Humankind should reflect and ponder on the impacts of the interaction of four major driving forces, referred as:

1) Geo-economics - regulated by the scarcity of natural resources and dominated by actors with different models of economic and social organization.

2) Technological progress - a central constituent in the construction of a new wave of globalization, based on a change of energy paradigm that slows growth limits and stimulates new international forms of organization, activities, network economy and differentiated digital tools. 
3) Demographics - diverging between "aging" developed and "young" developing countries.

4) Sustainability - forcing a trade-off to ensure the quality of life for future generations in the economic, environmental and social dimensions.

In the last six decades humanity has become richer and, according to (Sachs, 2002), Gross Domestic Product (GDP) has increased eightfold since 1950. There are about 1,020 million malnourished people and this number is likely to increase if the world community is not willing to face and negotiate the causes of this kind of situation. In recent decades, human economic activity has caused irreparable damage to the planet and there is no guarantee that ecosystems will continue to maintain the capacity to secure conditions for future generations. (UNDP, 2007)

How to face this reality? The economic approach has assumed that the solution is "development". However, the concept of "development" is quite ambiguous (Wolfe, 1996). Most researchers approach economic development as a process that generates economic, social, quantitative, and qualitative changes, which impact the national economy by increasing its real national output cumulatively and durably (Haller, 2012). Since the publication of the Brundtland Report, there have been several attempts to specify exactly the meaning of the term "Sustainable Development" (Pezzey, 1989; Lélé, 1991). The concept remains controversial (Giddings, Hopwood , \& O'Brien, 2002; (Barkemeyer, Holt, Preuss, \& Tsang, 2011), some of these definitions are "mutually exclusive" (Barkemeyer et al., 2011: 2) and the divergence of meanings and discourses has increased since the term emerged in 1987 (Daly \& Cobb, 1990; Reid, 1995; Baker, Kousis, Richardson, \& Young, 1997; Sauvé, 1999; Hopwood, Mellor, \& O'Brien, 2005; Redclift , 2005; Baker, 2006).

\section{Evolutionary perspective}

From an evolutionary perspective, concerns about sustainability emerged in the eighteenth and nineteenth centuries (Baker, 2006), through some thinkers expressing apprehension about the scarcity of resources, particularly in what regards to population growth (Malthus, 1798) and shortage of coal as a source of energy (Jevons, 1866). The industrial era revisited the issue, forcing the need to integrate environmental issues into economic policy (Dresner, 2002). In the 1950s, Fairfield Osborne (1953) and Samuel Ordway (1953), respectively, publishing the books "The Limits of the Earth" and "Resources and the American Dream," reemphasized the theme.

Since then, international policy has started to defend a different model of development and in the last five decades, there has been a long journey with advances and retreats around the concerns and policies. Four main distinct cycles may be summarized as Beginning, Retire, Endless loop and Standoff (Figure 1): 


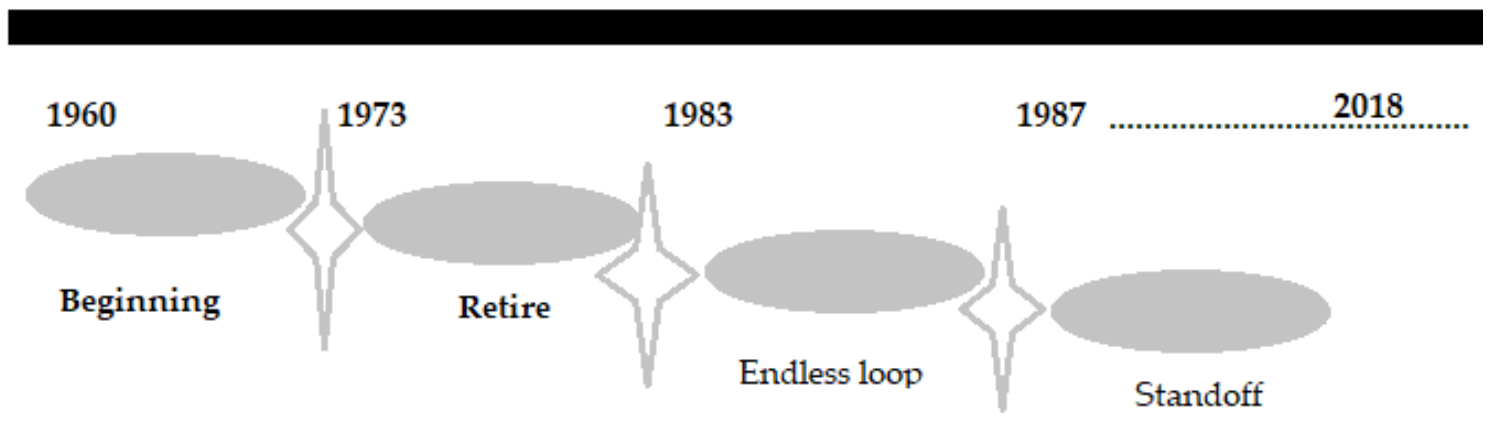

Fig. 1 - Different cycles of development models

\subsection{Beginning: $60 \mathrm{~s}$ and $70 \mathrm{~s}$, an expansive cycle}

The first period, from 1962 to 1973, was interrupted by the Yom Kippur war in October 1973 which was succeeded by the two oil crises of the 1970s. In 1962 the first alert works about the effects of the economy appeared.

This period was marked by the Vietnam War (1955-1975), the hippie movement and the intensification of anxiety about environmental issues, specifically the health impacts of industrial pollution. The first infrastructures of national environmental policies were launched in Japan (1967), the U.S. and Sweden (1969).

This concern initiated strategies that in some sectors have undergone "zero growth" strategies, especially after the 1972 publication of the Club of Rome report "The Limits to Growth" (Meadows \& Meadows, 1974). The report presented some challenging scenarios for global sustainability, based on a computational model of dynamic systems that simulated the interrelationship between five global economic subsystems: population, food production, industrial production, pollution, and consumption of non-renewable natural resources. The scenarios compiled by the Massachusetts Institute of Technology (MIT) team concluded that, if the same trends were to continue, the world would end in one hundred years: ecosystem would collapse; scarcity would arise and a war would erupt.

At the end of this cycle, in 1972, the first meeting on a planetary scale - the United Nations Conference on the Human Environment - took place in Stockholm, with the main purpose of resolving / debating the environmental problems that occurred after the great economic post World War II. Without concrete agreements, this conference had as its main virtue the "explosion" of environmental legislations and international agreements in the areas of nature conservation and pollution control. From these debates emerged the certainty that solutions to global problems are not limited to preventing the deterioration of the physical and biological environment, but also incorporate social, political and cultural scopes such as poverty and social exclusion (Barbieri, 2002). 


\subsection{Retire: 1973 to 1983 , a period dominated by the Oil Crisis and consequent economic instability}

The second period, from 1973 to 1983, was a period of retreat from the environmental agenda. It raised an international agenda to combat unemployment, economic recession and energy crises. The argument advocated by Meadows \& Meadows (1974) and Meadows, Meadows, \& Randers (1991) was reinforced by other reference studies, including "The Entropy Law and the Economic Process" (Georgescu-Roegen, 1971), "Toward a Steady State Economy" (Daly, 1973) and "Steady State Economics" (Daly, 1977) which recognize the absolute limits of economic growth.

The need for increased energy efficiency and conservation, particularly in Europe and Japan, has led to some free and indirect gains for the environment. It is in this context that the term "Sustainable Development" emerges for the first time in 1980 when the International Union for the Conservation of Nature and Natural Resources (IUCN) presented "The World Conservation Strategy", a strategy focused only on ecological sustainability (Baker, 2006). In 1982, the United Nations Convention on the Law of the Sea was signed, and in 1983, for the first time, an environmental Group ("Die Grünen") obtained parliamentary representation.

\subsection{Endless loop: 1983 to 1997, a growing internationalization of environmental discourse}

This period began in 1983 and lasted until 1997, when the Kyoto Protocol was signed. This was a time with a growing environmental discourse internationalization, with repercussions on legislation and creation of ministries of the environment in all developed countries. In 1983, the United Nations (UN) created the World Commission for Environment and Development.

It was published the Brundtland Report, was published in 1987, and in 1989 the Basle Convention was held to contribute to environmental protection in the field of waste control, specifically, transboundary movements of hazardous wastes and their disposal.

In 1992 the United Nations Conference on Environment and Development (UNCED) was held in Rio de Janeiro in 1992, where the concept of Sustainable Development was established by new and just global partnerships which created new levels of cooperation among States. Also known as Rio-92, this conference produced five important documents: i) Convention on Climate Change; (ii) the Convention on Biological Diversity; iii) Rio Declaration on Environment and Development; iv) Declaration of Principles on Forests; (v) Agenda 21.

Agenda 21 (Chapter 36) is one of the first documents to identify education as essential for achieving Sustainable Development (SD), with Education for Sustainable Development (ESD) emerging as an incentive tool under two complementary perspectives: the first, used to understand the complexities and synergies between issues that threaten the sustainability of the ecosystem; the second, to understand and evaluate their intrinsic values seeking to involve individuals in decision making in the search for a SD. 
Finally, to complete this period, the Kyoto Protocol was signed in 1997, in which the signatory countries agreed to reduce the emission of greenhouse gases. The objective was to achieve an average cut of around 5\% over 1990 levels, with a deadline to be achieved by 2012 (or more accurately in 2008-2012). The USA did not sign this Protocol.

\subsection{Standoff: post 1997, a growing demissionism in US environmental policy}

Beginning in 1997, the cycle is characterized by "growing resignation in US environmental policy" (Soromenho-Marques, 2003:12), reflected for example in the Kyoto Protocol (Dresner, 2002) and the reduction of the annual budget voted by the Congress to reduce the environmental liabilities of more than a century of industrialization (Soromenho-Marques, 2005).

The United Nations recognizes that progress made at the level of political discourse has not been effective (Miller \& Twinning-Ward, 2005) and in 2000 the Millennium Development Goals (MDGs) were signed by all countries. The World Summit for the SD, also known as the Earth Summit or Rio + 10, was held in Johannesburg, where long and difficult negotiations have took lace. Unlike Rio-92, which took place in a climate that favoured international cooperation, only three years after the fall of the Berlin Wall and the end of the Cold War (at a time when the thinking of cooperation prevailed over the logic of the conflict) Rio +10 took place in an opposite scenario, with a world increasingly marked by conflict and increasing social inequality, both in rich countries and in developing countries.

However, the results of the World Summit on SD were not achieved (Dresner, 2002). Nevertheless, the intense economic activity has enabled the recognition that the SD globally requires policies, procedures and principles defined based on intergovernmental cooperation, as well as the existence of a proactive civil society that verifies, monitors and promotes a campaign for change when confronted with situations of resistance, indifference or official denial (Blewitt, 2008).

In recent years, a new cycle has been established characterized by international awareness of the need to act. Several reports from independent bodies, some natural disasters become more frequent and their link to climate change is perceived. The media gradually contributed to sensitizing the population, paying increasing attention to the phenomenon.

In 2007, the Nobel Peace Prize was jointly awarded by the Vice-President Al Gore and the Intergovernmental Panel on Climate Change (IPCC) "for their efforts to build and disseminate greater knowledge about human-induced climate change, and lay the foundations for the measures that are necessary to counteract such changes" (IPPC, Nobel Prizes and Laureates, 2007).

In 2009, the 15th United Nations Climate Change Conference (COP15) was held in Copenhagen, bringing together heads of state from 193 countries, a summit of global leaderships unprecedented in the recent history of diplomacy and with such a high degree of mobilization of civil society.

More recently, and despite intense efforts to prepare for the Rio +20 conference, the event has also fallen short of expectations. The final document, entitled "The Future We 
Want," only mentions that "the formulation of goals could be useful for launching a coherent and focused action on Sustainable Development," with "coherent and integrated objectives in the Development Agenda for United Nations beyond 2015, thus contributing to the achievement of Sustainable Development and serving as a guide for the implementation and integration of Sustainable Development in the United Nations system as a whole" (Rio+20, 2012: 48).

The Aichi-Nagoya Declaration was unanimously adopted in November 2014 based on the results of the United Nations Decade of Education for Sustainable Development (ESD) (2005-2014) and in the deliberations of the Conference and participant meetings held on the 4th to 8th of November in Okayama.

In September 2015, at the United Nations summit in New York, the Sustainable Development Goals were established integrated and indivisible objectives, which balance the three dimensions of sustainable development: economic, social and environmental. The action agenda was extended until 2030, with the goals and targets set to stimulate action over the next fifteen years in areas of crucial importance to both humanity and the planet.

The first Conference of the Parties to the United Nations Framework Convention on Climate Change (COP21), also known as the "Climate Conference", was held in November / December 2015, ending a "historic agreement" on global warming. With a type of Agreement of a different nature than the Kyoto Protocol, the Paris Agreement has allowed for a longer-term architecture, with increased ambition of the commitments by all countries, and their mitigation commitments for commitment future periods.

In November 2016, the 22nd Conference of the Parties to the United Nations Framework Convention on Climate Change (COP22) was held in Marrakesh. 2018 was indicated as the deadline for the beginning of the operation of Paris and, once again, important initiatives and mobilizations were announced by companies, investors, cities and local governments. In the meantime, Donald Trump becomes president of the United States, one of the largest countries emitting greenhouse gas emissions in the world. On June $1^{\text {st }} 2017$ Trump's new administration announces the US exit from the Paris climate deal, claiming that this decision is the way to give new impetus to the US economy and negotiate a "fair" agreement for the country. Trump, who has expressed doubts that man-made greenhouse gas emissions are the prime cause of global warming, also announced in June that he intended to pull out and instead promote U.S. coal and oil industries (Graham, 2017). The impasse continues, and the world awaits a rethink of the USA positioning. New worldwide actors assume new positions and join efforts to find a real solution, before it is too late.

\section{Conclusion}

Central concerns on economic growth and development are daily political issues, but no global solutions have until now been really started. Sustainable Development is not only a practice of corporate social responsibility to gain a competitive edge, but is specially a requirement to meet the needs of future generations. The challenges are 
giants and the economic dimension cannot overlap with the balance of social and environmental dimensions.

Nowadays we are observing an increasing involvement of countries in the definition of joint strategies and actions, but it is not enough. We are going through a phase of great instability where desirable international cooperation is often called into question, contributing to a continued stalemate. There is a clear need for paradigm shifting and civil society are the kernel for the needed change strategy, with clear and strong perspectives based on identified collective shared visions.

\section{References}

Abranches, S. (2010). A COP15: apontamentos de campo. Estudos Avançados. São Paulo, v. $24, n .68,2010,24: 68$.

Azevedo, F. (2011). Limites do Crescimento. Cenários. Tendências e Futuros na Economia Global, n. 16.

Baker, S. (2006). Sustainable Development. Routledge.

Baker, S., Kousis, M., Richardson, D., \& Young, S. (1997). The Politics of Sustainable Development: Theory, Policies and Practive withn the European Union. London, UK: Routledge.

Barbieri, K. (2002). The Liberal Illusion: Does Trade Promote Peace? . University of Michigan Press: Ann Arbor.

Barkemeyer , R., Holt, D., Preuss, L., \& Tsang, S. (2011). What happened to the "development" in sustainable development? Business guidelines two decades after Burndtland. Obtido de Published online in Wiley Online Library. DOI: 10.1002/sd.521Sustainable Development.

Blewitt, J. (2008). Understanding sustainable development. Earthscan.

Bonnett, M. (1999). Education for sustainable development: a coherent philosophy for environmental education? Cambridge Journal of Education, 29: 3, 12-17.

Clive, H. (2010). Requiem for a Species: Truth about Climate Change. Earthscan.

Daly, H. (1973). Toward a Steady-state Economy. W. H. Freeman.

Daly, H. (1977). Steady-State Economics: The Political Economy of Bio-Physical Equilibrium and Moral Growth. San Francisco, CA: W.H. Freeman \& Co.

Daly, H., \& Cobb, J. (1990). For the Common Good. London: Green Print.

Dresner, S. (2002). The principles of Sustainability. Earthscan.

Ferreira, J. (2012). A Sustentabilidade do Alto Douro Vinhateiro: Realidade ou Utopia? Contributo para a avaliação e melhoria da sustentabilidade da região. Faculdade de Ciências Sociais e Humanas. Universidade Nova de Lisboa: Tese de Doutoramento em Geografia e Planeamento Territorial. Especialidade em Geografia Humana.

Georgescu-Roegen, N. (1971). The Entropy Law and the Economic Process (Vol. Feb. 5). Harvard University Press. 
Giddings, B., Hopwood , B., \& O'Brien, G. (2002). Environment, economy and society: fitting them together into sustainable development. Sustainable Development. Sustainable Development, 10, 187-196.

Gow, K. (2009). Meltdown: Climate Change, Natural Disasters and other Catastrophes - Fears and Concerns of the Future. Nova Science Publishers, Incorporated.

Graham, R. (2017). Mail Online. Obtido de Daily Mail: http://www.dailymail.co.uk/news/article-5059743/Donald-Trump-not-invitedParis-Climate-Change-Summit.html

Haller, A. (2012). Concepts of Economic growth and Development. Challenges of crisis of knowledge. Economy Transdisciplinarity Cognition, 15(1), 66-71.

Hardin, G. (13 de Dec. de 1968). The Tradegy of the Commons. Science, New series, 162, № 3859, 1243-1248.

Harris, G. (2007). Seeking Sustainability in an Age of Complexity. Cambridge, UK: Cambridge University Press.

Hopwood, B., Mellor, M., \& O'Brien, G. (2005). Sustainable Development: Mapping Different Approaches. Sustainable Development, 13, 38-52.

IPPC. (2007). Climate Change 2007: Synthesis Report. Geneva, Switzerland: IPPC.

IPPC. (2007). Nobel Prizes and Laureates. Obtido de Nobelprize-org: https://www.nobelprize.org/nobel_prizes/peace/laureates/2007/

Jevons, W. (1866). The Coal Question; An Inquiry concerning the Progress of the Nation, and the Probable Exhaustion of our Coal-mines. London: Macmillan and Co.

Kostyuchenko, Y., \& Bilous, Y. (2009). Long-Term Forecasting of Natural Disasters Under Projected Climate Changes in Ukraine. Em I. S. Groisman P.Y., Regional Aspects of Climate-Terrestrial-Hydrologic Interactions in Non-boreal Eastern Europe. NATO Science for Peace and Security Series C: Environmental Security. Dordrecht: Springer.

Lélé, S. (1991). Sustainable development: a critical review. World Development, 19, 607621.

Malthus, T. (1798). An Essay on the Principle of Population. London. St. Paul's ChurchYard: J. Johnson.

Meadows, D., \& Meadows, D. (1974). The limits to Growth: A Report for the Club of Rome's Project on the Predicament of Mankind. Universe Books.

Meadows, D., Meadows, D., \& Randers, J. (1991). Beyond the Limits: confronting global collapse, envisioning a sustainable future. EUA: Chelsea Green Pub Co.

Middleton, N. (2013). The Global Casino: An Introduction to Environmental Issues. Routledge.

Miller, G., \& Twinning-Ward, L. (2005). Monitoring for Sustainable tourism transition: the challenge of developing and using indicators. CAB|Publishing.

O' Riordan, T. (1981). Environmentalism. London: Pion Press.

Pezzey, \& J. (1989). Sustainable development concepts. The World: World Bank Environment paper $\mathrm{n}$ ㄴ2. 
Redclift, M. (2005). Sustainable development (1987 - 2005): an oxymoron comes of age. Sustainable Development, 212-227.

Reid, D. (1995). Sustainable Development - An Introductory Guide. London: Earthscan.

Rio+20. (2012). O Futuro que Queremos. Declaração Final da Conferência das Nações Unidas sobre Desenvolvimento Sustentável, (p. 48).

Robbins, P., Hintz, J., \& Moore, S. (2010). Environment and Society: A Critical Introduction. John, Wiley \& Sons.

Sachs, I. (2002). Caminhos para o Desenvolvimento Sustentável. Rio de Janeiro: Garamond.

Sam Love, D. (1972). Ecotage. Pocket Books.

Sauvé, L. (1999). La educación ambiental entre la modernidad y la posmodernidad: en busca de un marco de referencia educativo integrador. Tópicos en Educación Ambiental, 1(2), 7-25.

Schumacher, E. (1973). Small Is Beautiful. USA: Harper \& Row, Publishers, Inc.

Smith, K., \& Petley, D. (2009). Environmental Hazards: Assessing Risk and Reducing Disaster. Routledge.

Soromenho-Marques, V. (2003). As idades da Política Internacional de Ambiente. Fórum Ambiente, nำ 85, 5-6.

Soromenho-Marques, V. (2005). Política Internacional de Ambiente e Desenvolvimento Sustentável. Balanço e Perspetivas. Em Metamorfoses. Entre o Colapso e o Desenvolvimento Sustentável (Vols. I Parte, 2o Ensaio, pp. 37-62). Mem Martins: Publicações Europa América.

Stern. (2006). Stern Review Report on the Economics of Climate Change. HM Treasury, disponível em http://webarchive.nationalarchives.gov.uk/20130129110402/http://www.hmtreasury.gov.uk/stern_review_report.htm.

Troszczynska-Van Genderen, Ramet, V., \& Vicario, L. (2012). Much Ado about Nothing: The Rio+20 conference. Directorate-General for External Policies. Policy Department. European Parliament. June 2012.

UNDP. (2007). Human Development Report 2007/2008: Fighting Climate Change: Human Solidarity in a Divided World (United Nations Development Programme). Palgrave Macmillan, New York: UNDP.

Wolfe, M. (1996). Elusive Development. London: Zed Books. 